\title{
Studies on dietary hypocholesterolemic agent in Briolers
}

El-Boushy, M.E., *Abdalla, O. M., Engy F. Risha , Heba, A. A. and **EL-Nagar, A.

Dept of Clinical Pathology and ** Dept of Pathology, Fac. Vet. Med., Mansoura University. *Dept of Clinical Pathology, Fac. Vet. Med., Suez Canal University

\section{ABSTRACT}

In the present study, we evaluated and tested the hypocholesterolemic effect of statin (atorvastatin) in chickens. Thirty six (36) of one day old Cobb chicks were kept for 2 weeks for adaptation then divided into 3 equal groups each (12). Control (Gp.1) did not receive any treatment.GP-2 treated orally with $0.02 \%$ atorvastatin $(0.2 \mathrm{gm} / \mathrm{kg}$ ration). GP-3 treated orally with $0.05 \%$ atorvastatin $(0.5 \mathrm{gm} / \mathrm{kg}$ ration).Serum and whole blood sample were collected from all groups $2^{\text {nd }}$ week and $4^{\text {th }}$ week post treatment to evaluate some hematological and biochemical changes as well as immunomodulatory cytokines TNF- $\alpha$, IL1 $\beta$, and IL6.

Oral treatment of the atorvastatin caused significant benefit results in chickens appeared in the correction of some biochemical parameters also try to stimulate cytokine response represents in TNF- $\alpha$, IL1 $\beta$, and IL6.

From the present work, it could be concluded that statin (atorvastatin) has potent hypocholesterolemic effect, this appear in the correction with hematological, biochemical and immunological results.

\section{INTRODUCTION}

Poultry industry in recent years has occupied a leading role among agricultural industries in many parts of the world. The potential for further growth is obvious in view in the value of eggs and poultry meat as basic protective foods in the human diets. The increase of poultry meat production during the past decade in developing regions was in average $43 \%$, while in the developed regions it was only 28.4\% (Daghir, 1995) .The size of the poultry industry has been made possible by the introduction of intensive production systems utilizing new technologies. Successful disease control has been a necessary corollary to the efficiency of such systems. Thus recognition, treatment or prevention of disease is of crucial importance (Jordan, 1990).

Cholesterol is not a life-threatening toxin, it has many benefits, but cholesterol can also create problems. Cholesterol in the bile can crystallize to form gall stones that may block the bile ducts. 
Cholesterol is also strongly implicated in the development of atherschelorosis: fatty deposits (plaques) that form on the inside of blood vessels and predispose to heart attacks. The major culprit seems to be levels of LDLs that are in excess of the body's needs (Wainwright, 2005).

Statins, inhibitors of 3-hydroxy-3methylglutaryl-coenzyme A (HMG$\mathrm{CoA}$ ) reductase, have revolutionized the treatment of hypercholesterolemia. They are the most efficient agents for reducing plasma cholesterol, being also appreciated for their good tolerance (Wainwright, 2005). Atorvastatin (AT) differs from other statins in that it has a longer action and presents active metabolites which are biotransformed mainly by cytochrome P3A4 in the liver (Clarke and Mills, 2006).

Chickens were chosen as our experimental model because of the similarity of their lipid metabolism to that of human. The relative contribution of various tissues to overall fatty acids and cholesterol synthesis differs among animal species. All fatty acids synthesis takes place in the liver of chicken and humans, whereas in rats and swine, adipose tissue is appetitively inhibits the conversion of HMGCOA to mevalonic acid, a substrate for cholesterol synthesis (Parkre et al, 1993; Goldstein and Brown, 1990; Nakanishi et al, 1988; Brown and Goldstein, 1986 and Illingrowth, 1987).
The objective of the present work to evaluate the hypocholesterolemic effect of statin (atorvastatin) in chickens.

\section{MATERIAL AND METHODS:}

1. Laboratory animals used:

Thirty six (36) one day old Cobb chicks were obtained from national hatchery in Mansoura Governorate. The chicks were housed in batteries and fed formulated balanced ration and water were supplied all the day.

2. Treatment drug:

Atorvastatin, Hunan Dinuo pharmaceutical Co., China.

\section{Haematological test:}

Erythrocytes (RBCs) and white blood cell count (WBC), calculation of blood indices according to Feldman et al (2000) packed cell volume (PCV) (Barbra, 1988) haemoglobin $(\mathrm{Hb})$ levels (Drabkin, 1949) and differential leukocytic count (Coles, 1986).

\section{Serum biochemical analysis:}

Prepared frozen samples were used and analyzed for some serum analysis including AST, lactate dehydrogenase, creatinine, uric acid, total protein, albumin, globulin ,A/G ratio, total lipids, cholesterol, HDL cholesterol, LDL cholesterol, triglycerides, Catalase , Lipid peroxidase and Glutathione reduced were determined with semi-automatic spectrophotometer (BM-Germany 5010) using commercial test kits (Randox Co. UK.) according to enclosed pamphlet.

\section{Immunological studies:}


Tumor necrosis factor $-\alpha(\operatorname{TNF} \alpha)$ was assayed by Enzyme Amplified Sensitivity Immunoassay (EASIA) performed on microplate (BioSource, Co. Belgium). The assay uses monoclonal anti-bodies (MAbs) directed against distinct epitopes of TNF- $\alpha$ acc ording to (Aukrust et al, 1994).

ILI $\beta$ and IL6 were assayed by ready made Chicken Interleukin-1 beta and Interleukin-6 ELISA Kit provided by Themo scientific company according to (Chan and Perlstin, 1987).

\section{Statistical analysis:}

Our results were analyzed by (ANOVA) using SPSS software statistical program (SPSS for windows (ver.15.00, USA). Two groups were significantly different if $\mathrm{P}$ value was statistically lower than 0.05 .

\section{RESULTS \& DISCUSSION}

Administration of atorvastatin in our work moderate doses did not lead to unfavorable hematological changes (table1-2).These observations are suggestive of the protective effect of atorvastatin.

Liver transminase enzymes (AST) act as indicator on the statue of the liver and liver function, alteration in the enzyme level may be indicator on hepatic disease, but AST enzyme alone not specific hepatic enzyme, as shown in atorvastatin treated groups, transient elevation in AST level with rapidly return to normal (table-3), which is confirmed histopathologically by centrolobular vacuolar degeneration, focal hepatic necrosis and dilated sinusoids besides some coagulative necrosis of some hepatocytes infiltrated with round cells (figure2-3), this may be agree with Gehan and Manal (2010) who observed an increase in the AST serum level at high dose of atorvastatin $\quad(80 \mathrm{mg} / \mathrm{kg}), \quad$ and confirmed histopathologically by severe hepatic changes were observed with high dose atorvastatin $(80 \mathrm{mg} / \mathrm{kg})$. In addition, cloudy swelling, hydropic degeneration and hepatic necrosis were the most predominant lesions. Such lesions were induced via the formation of free radicals, especially the reactive oxygen species. In consistent with the present findings, the hepatotoxic effect of high dose atorvastatin was ameliorated with partial disappearance of hepatic damage after treatment. Thus, the antioxidant effect of atorvastatin appears to play role in the attenuation of hepatic injury. The mechanism by which statins cause asymptomatic elevation in aminotransferases is unknown.

Most of the HMG-COA reductase inhibitors are metabolized by the liver. Damage to this organ is assessed by a persistent elevated level of its aminotransferases: ALT and AST (Black, 2000). Statins treatment commonly leads to an increase of ALT and AST which is dose dependent (Parra et al, 2003). The increase in aminotransferases levels more than three times the 
upper normal limit indicates a potential liver toxicity (Veillard and Marsh, 2002 and Waters, 2005). Minor sporadic elevations in ALT, AST were observed for the atorvastatin-treated

patients

(Rebecca et al, 1997).

Uric acid is a major end product of nitrogen metabolism in birds. It constitutes approximately $60-80 \%$ of total excreted nitrogen in avian urine. Uric acid is synthesized in liver and $90 \%$ is excreted via tubular secretion largely independent of urine flow rate (Kaneko et al, 1997). Small quantities of creatinine are ingested by animals consuming diets containing animal tissues, since creatinine is distributed throughout the body water. Muscle tissue contains phosphocreatinine, which undergoes spontaneous crystallization with loss of organic phosphate to form creatinine. Creatinine circulates in plasma and mainly excreted by kidney (Kaneko et al, 1997). Our results revealed insignificant change in creatinine and uric acid the chickens treated with $0.02 \%$ and $0.05 \%$ atorvastatin in the all groups along the whole experiment (table-3), so atorvastatin alone had no nephrotoxic effect, which is confirmed histopathologically by no changing in renal tissue of chickens after treatment with atorvastatin.

Dietary cholesterol is present in both free and esterified forms ,but only nonesterified cholesterol is absorbed and cholesterol ester are hydrolyzed within the lumen of the intestine by sterol esterase secreted by pancreas. The type of triglyceride present in diet significantly affects the absorption of cholesterol and its distribution in lymph lipids (Kaneko et al, 1997). Our results showed significant decrease in serum cholesterol and LDL cholesterol, HDL cholesterol, triglyceride and total lipid in the chickens treated with $0.02 \%$ and $0.05 \%$ atorvastatin in the 2 nd week and 4th week (table-4), agreed with Asaf and David (2000) who observed significant decrease in cholesterol and LDL cholesterol (bad cholesterol) due to apart of lovastatin molecule resembles the structure of HMG-COA. For that reason, lovastatin and several compounds of this group act as competitive inhibitors of HMGCOA reductase enzyme.

Two mechanisms of action attributed to reductase inhibitors are the indirect result of decreased cholesterol synthesis in the hepatocyte. The first and most commonly cited mechanism is an increase in LDL receptor expression (Ma et al, 1986). The second mechanism, although not widely discussed, is a decrease in the production and secretion of VLDL (Naoumova et al, 1996; Kasim et al, 1992). Atorvastatin has a liverselectivity ratio in animals that is intermediated between pravastatin, lovastatin ,fluvastatin, and atorvastatin is more effective in inhibiting liver cholesterol synthesis 
than either pravastatin or lovastatin (shaw et al, 1990).

Also, we agreed with Istvan and Deisenhofer (2001) who revealed that statins also have the ability to bind HMG-CoA reductase more potently than HMG-CoA leading to the inhibition of HMG-CoA reductase, and subsequently reduction in cholesterol synthesis in the liver. That inhibition induces hepatocytes to increase their surface expression of LDL-receptors, so as to increase uptake of LDL and reduce plasma cholesterol, also Robert et al (2006) reported decrease in plasma total cholesterol. The regulation of HMG-COA expression can be controlled at the level of transcription, as well as by changes in mRNA translation and stability and phosphorylation (Edward and Davis, 1996). In agreement with HMG-COA gene expression being down regulated in the presence of high circulating cholesterol levels (Goldstein and Brown, 1990). Also, Uma et al (2008) observed that atorvastatin (10 and $80 \mathrm{mg} /$ day) in subjects with metabolic syndrome dose dependently decreased total, LDL, and oxidized LDL cholesterol. In addition Kim et al (2004) studied the effects of pravastatin were compared with lovastatin and simvastatin in laying hens. Pravastatin is a potent HMGRinhibiting drug, known to cause liver specific inhibition of cholesterol synthesis.
Exposure of lipids in cell membrane to free radicals stimulates the process of lipid peroxidatin. The products of lipid peroxidation are themselves reactive species and lead to extensive membrane, organelles and cellular damage. The free radical activity and the extent tissue damage are related quantitatively to the amount of lipid peroxide level in the blood (Davidraj et al, 2008). Lipid peroxidation is a general mechanism, whereby free radicals induce tissue damages, and implicated under several diverse pathological conditions (Saeed et al, 2009). Catalase and Malondialdehyde (MDA) are considered as biomarker for the assessment of lipid peroxidation. Another class of actions for statins and a potential mechanism by which statins may improve endothelial function is through their antioxidant effects through our results which showed significant decrease in Catalase and Malondialdehyde (MDA) in the chickens treated with $0.05 \%$ and $0.02 \%$ atorvastatin (table-5). We agreed with Martha et al (2008) who measured serum MDA levels as a parameter for lipid peroxidation and observed a significant reduction in the lipid peroxidation with both the drugs atorvastatin and clopidogrel before and after the treatment period in various experimental groups. The degree of reduction was more or less same with both the drugs, but with the 
combined treatment, there was less reduction in the lipid peroxidation. Oxidative stress may cause vascular damage and dysfunction and initiate a cascade of events that ultimately lead to atherosclerosis. Also agreed with Karatzis et al (2005) who reported that pravastatin therapy caused an early significant decrease in serum malondialdehyde concentration. In addition partially agreed with Gehan and Manal (2010) who reported that atorvastatin alone decreased malondialdehyde, but increased catalase and superoxide dismutase (SOD) levels.

SOD catalyzes thedismutation of $\mathrm{O} 2$ in to oxygen and ${ }_{\mathrm{H} 2 \mathrm{O} 2}$, and while it is an important antioxidant defense mechanism in aerobic organisms, excessive SOD activity may be deleterious (Saeed et al, 2009). Our results revealed that Superoxide dismutase (SOD) serum level in the chickens treated with $0.02 \%$ and $0.05 \%$ atorvastatin showed significant decrease (table-5). We agreed with Uma et al (2008) who examined other markers of oxidative stress, such as urinary nitrotyrosine, F2-isoprostanes, and monocyte Superoxide release and showed significant decrease effect on these measures. Also, Ebru et al (2011) reported the significant decrease in superoxide dismutase activity in erythrocytes after 8 weeks of atorvastatin treatment; indicate the antioxidant effect of the drug.
Glutathione reduced (GSH) is the major intracellular non-protein thiol compound, and plays a major role in the protection of cells and tissue structures from oxidative injury. Erythrocytes play an important role in the delivery of GSH to tissues with high rate of GSH utilization (Anderson and Meister, 1989). On the other hand, protects protein thiol groups from oxidation by serving as a biological redox agent (Stadtman, 2004 and Meister and Anderson, 1983). Our results showed significant decrease in GSH level in the 2nd week in the chickens treated with $0.02 \%$ and $0.05 \%$ atorvastatin (table-5). However, in the 4th week GSH was decreased significantly for the chickens treated with $0.02 \%$ atorvastatin. We agreed with $\boldsymbol{A y d i n}$ et al (2009) who reported that atorvastatin therapy caused significant decreases in MDA and GSH levels.

The inhibition of lipid peroxidation observed with atorvastatin might be secondary to lipid lowering effect as well as its antioxidant effects (Yogendrasinh and Rajendra, 2010).

No significance changed in biochemical parameters in atorvastatin treated groups. atorvastatin is without having any serious toxicity or side effects known and thus can be safely used (table-3).

TNF- $\alpha$ is amplify, and coordinate proinflammatory sign also, resulting in the synchronized expression of effectors molecules that mediate 
diverse aspects of innate immunity. TNF is capable of eliciting expression of chemokines and adhesion molecules and thus may be critical to the recruitment of neutrophils from the blood and has severe damage to the target organs (Isogai et al, 1998 and Joseph et al, 2001). The transcription factor NFkB regulates the expression of cytokines, chemokines, adhesion factors, and inducible pro inflammatory receptors .The abnormal activation of NFkB has been established for a series of inflammatory diseases and cancer.

IL1 $\beta$ Produced by activated macrophages, IL-1 stimulates thymocyte proliferation by inducing IL-2 release, B-cell maturation and proliferation, and fibroblast growth factor activity. IL-1 proteins are involved in the inflammatory response, being identified as endogenous pyrogens, and are reported to stimulate the release of prostaglandin and collagenase from synovial cells.

IL-6 is one of the most important mediators of fever and of the acute phase response. It is capable of crossing the blood brain barrier (Bastard et al, 1999) and initiating synthesis of Prostaglandin E2 (PGE2) in the hypothalamus, thereby changing the body's temperature setpinnate immune system, called pattern recognition receptors (PRRs), including Tolllike receptors (TLRs).IL-6 is responsible for stimulating acute phase protein synthesis, as well as the production of neutrophils in the bone marrow. It supports the growth of B cells and is antagonistic to regulatory $\mathrm{T}$ cells. Our esults showed that IL1 $\beta$, IL6, $\mathrm{TNF} \alpha$ serum level in chickens treated with atorvastatin (AT0.02\& AT0.05) significant increase in comparison with control group (table-6), which agreed with Michel et al (2005) who studied the antiinflammatory and analgesic effects of atorvastatin in a rat model of adjuvant- induced arthritis received $1-10 \mathrm{mg} / \mathrm{kg}$ atorvastatin for $10-15$ days. They reported that atorvastatin caused inhibition of the increase of paw volume, increased of amyeloperoxidase activity in arthritic animals, and had stimulatory effect on the local expression of all cytokines and inhibition of IL-1 $\beta$, TNF- $\alpha$, IL-6.

Histopathological examination did not show any change in lung, spleen, bursa, heart, intestine and kidney except changes in hepatic tissue at $2^{\text {nd }}$ week post treatment with atorvastatin (figure 2-3), but at $4^{\text {th }}$ week post treatment did not show any change which agreed with Gehan and Manal (2010). 
Table (1): Erythrogram Parameters (Mean \pm S.E.) in Chickens experimentally treated with atorvastatin.

\begin{tabular}{|c|c|c|c|c|c|c|c|}
\hline $\begin{array}{l}\text { Time/ } \\
\text { Week }\end{array}$ & Group & $\begin{array}{c}\text { RBC } \\
\times 10^{6} / \mu L\end{array}$ & $\begin{array}{l}\text { Hb } \\
\text { g/dl }\end{array}$ & $\begin{array}{c}\text { PCV } \\
\%\end{array}$ & $\begin{array}{c}\text { MCV } \\
\text { fl }\end{array}$ & $\begin{array}{c}\mathrm{MCH} \\
\mathbf{P g}\end{array}$ & $\begin{array}{c}\text { MCHC } \\
\%\end{array}$ \\
\hline \multirow{3}{*}{$\begin{array}{c}2^{\text {nd }} \\
\text { week }\end{array}$} & Cont. & $2.56 \pm 0.13 a$ & $8.24 \pm 0.5 \mathrm{a}$ & $30 \pm 1.27 \mathrm{a}$ & $117.8 \pm 5.59 a$ & $33.4 \pm 1.92 \mathrm{a}$ & $29.6 \pm 2.3 \mathrm{a}$ \\
\hline & AT 0.02 & $2.8 \pm 0.12 \mathrm{a}$ & $9.27 \pm 0.24 \mathrm{a}$ & $31 \pm 0.71 \mathrm{a}$ & $118.2 \pm 4.12 \mathrm{a}$ & $33.2 \pm 1.25 \mathrm{a}$ & $28.1 \pm 0.24 a$ \\
\hline & AT 0.05 & $2.52 \pm 0.09 \mathrm{a}$ & $8.66 \pm 0.41 \mathrm{a}$ & $30.4 \pm 0.98 a$ & $128.5 \pm 1.83 \mathrm{a}$ & $34.4 \pm 1.16 \mathrm{a}$ & $25.9 \pm 1 \mathrm{a}$ \\
\hline \multirow{3}{*}{$\begin{array}{c}4^{\text {th }} \\
\text { week }\end{array}$} & Cont. & $2.33 \pm 0.05 \mathrm{a}$ & $7.83 \pm 0.27 a$ & $36.4 \pm 0.98 a$ & $156.52 \pm 6.2 \mathrm{a}$ & $33.7 \pm 1.8 \mathrm{a}$ & $21.55 \pm 0.87 a$ \\
\hline & AT 0.02 & $2.56 \pm 0.12 \mathrm{a}$ & $7.63 \pm 0.36 \mathrm{a}$ & $36.8 \pm 1.36 \mathrm{a}$ & $144.96 \pm 8.9 \mathrm{a}$ & $30.1 \pm 2 a$ & $33.7 \pm 0.79 a$ \\
\hline & AT 0.05 & $2.62 \pm 0.21 \mathrm{a}$ & $7.73 \pm 0.43 a$ & $35.2 \pm 1.86 \mathrm{a}$ & $135.62 \pm 6.6 a$ & $29.7 \pm 0.96 a$ & $34.9 \pm 0.79 a$ \\
\hline
\end{tabular}

Table (2): Leukogram Picture (Mean \pm S.E.) in Chickens experimentally treated with atorvastatin.

\begin{tabular}{|c|c|c|c|c|c|c|c|}
\hline $\begin{array}{c}\text { Time } \\
/ \\
\text { Week }\end{array}$ & $\begin{array}{c}\text { Grou } \\
\mathbf{p} \\
\end{array}$ & $\begin{array}{c}\text { TLC } \\
\times 10^{3} / \mu \mathrm{L}\end{array}$ & $\begin{array}{c}\text { Heterophils } \\
\times 10^{3} / \mu \mathrm{L}\end{array}$ & $\begin{array}{c}\text { Lymphoc } \\
\text { ytes } \\
\times 10^{3} / \mu \mathrm{L} \\
\end{array}$ & $\begin{array}{c}\text { Monocytes } \\
\times \mathbf{1 0}^{3} / \mu \mathrm{L}\end{array}$ & $\begin{array}{c}\text { Eosinophils } \\
\times 10^{3} / \mu \mathrm{L}\end{array}$ & $\begin{array}{c}\text { Basophils } \\
\times 10^{3} / \mu \mathrm{L}\end{array}$ \\
\hline \multirow{3}{*}{$\begin{array}{c}2^{\text {nd }} \\
\text { week }\end{array}$} & Cont. & $17.6 \pm 1.166 \mathrm{a}$ & $7.4 \pm 0.51 \mathrm{a}$ & $9.7 \pm 1.2 \mathrm{a}$ & $0.47 \pm 0.1 \mathrm{a}$ & $0.46 \pm 0.21 \mathrm{a}$ & $0.0 \pm 0.0$ \\
\hline & $\begin{array}{c}\text { AT } \\
0.02\end{array}$ & $11.88 \pm 2.332 \mathrm{a}$ & $9.4 \pm 1.7 \mathrm{a}$ & $8.5 \pm 1.2 \mathrm{a}$ & $0.64 \pm 0.2 \mathrm{a}$ & $0.09 \pm 0.09 a$ & $0.0 \pm 0.0$ \\
\hline & $\begin{array}{c}\text { AT } \\
0.05 \\
\end{array}$ & $16.4 \pm 1.166 \mathrm{a}$ & $7.2 \pm 1.3 \mathrm{a}$ & $8.4 \pm 0.47 \mathrm{a}$ & $0.54 \pm 0.2 \mathrm{a}$ & $0.2 \pm 0.13 \mathrm{a}$ & $0.13 \pm 0.13$ \\
\hline \multirow{3}{*}{$\begin{array}{c}4^{\text {th }} \\
\text { week }\end{array}$} & Cont. & $20 \pm 2.449 \mathrm{a}$ & $12.1 \pm 1.96 \mathrm{a}$ & $7.31 \pm 1.37 \mathrm{a}$ & $0.11 \pm 0.11 \mathrm{a}$ & $0.5 \pm 0.23 a$ & $0.0 \pm 0.0$ \\
\hline & $\begin{array}{c}\text { AT } \\
0.02 \\
\end{array}$ & $18.4 \pm 2.135 \mathrm{a}$ & $11.9 \pm 1.42 \mathrm{a}$ & $5.78 \pm 0.8 \mathrm{a}$ & $0.09 \pm 0.09 \mathrm{a}$ & $0.5 \pm 0.22 \mathrm{a}$ & $0.0 \pm 0.0$ \\
\hline & $\begin{array}{c}\text { AT } \\
0.05 \\
\end{array}$ & $15.2 \pm 1.854 \mathrm{a}$ & $8.34 \pm 1.33 \mathrm{a}$ & $6.29 \pm 1.75 \mathrm{a}$ & $0.08 \pm 0.08 \mathrm{a}$ & $0.38 \pm 0.17 \mathrm{a}$ & $0.0 \pm 0.0$ \\
\hline
\end{tabular}

Means in the same column not followed by the same letter differ significantly $(\mathrm{P}<0.05)$.

Table (3): Some Biochemical Parameters Mean ( \pm S.E.) in Chickens experimentally treated with atorvastatin.

\begin{tabular}{|c|c|c|c|c|c|c|c|c|c|}
\hline $\begin{array}{c}\text { Tim } \\
\text { e/ } \\
\text { We } \\
\text { ek }\end{array}$ & $\begin{array}{c}\text { Grou } \\
\text { p }\end{array}$ & $\begin{array}{l}\text { Uri A } \\
\text { mg/dl }\end{array}$ & $\begin{array}{c}\text { Creatin } \\
\text { ine } \\
\text { mg/dl }\end{array}$ & $\begin{array}{c}\text { T.Prot } \\
\text { ein } \\
\text { g/dl }\end{array}$ & $\begin{array}{c}\text { Albu } \\
\text { min } \\
\text { g/dl }\end{array}$ & $\begin{array}{c}\text { Globu } \\
\text { lin } \\
\text { g/dl }\end{array}$ & $\begin{array}{c}\text { A/G } \\
\text { Ratio }\end{array}$ & $\begin{array}{c}\text { AST } \\
\text { U/L }\end{array}$ & $\begin{array}{c}\text { LDH } \\
\text { U/L }\end{array}$ \\
\hline \multirow{3}{*}{$\begin{array}{c}\mathbf{2}^{\text {nd }} \\
\text { wee } \\
\mathbf{k}\end{array}$} & Cont. & $\begin{array}{l}5.58 \pm \\
0.24 \mathrm{a} \\
\end{array}$ & $\begin{array}{c}0.33 \pm \\
0.025 \mathrm{a} \\
\end{array}$ & $\begin{array}{l}3.12 \pm \\
0.22 \mathrm{a}\end{array}$ & $\begin{array}{l}0.91 \pm \\
0.48 \mathrm{a} \\
\end{array}$ & $\begin{array}{l}2.21 \pm \\
0.21 \mathrm{a} \\
\end{array}$ & $\begin{array}{c}0.43 \pm 0 . \\
52 \mathrm{a}\end{array}$ & $\begin{array}{c}20.3 \pm \\
1.3 \mathrm{a} \\
\end{array}$ & $\begin{array}{c}2227.5 \pm \\
61.11 \mathrm{a} \\
\end{array}$ \\
\hline & $\begin{array}{c}\text { AT } \\
\text { 0.02 }\end{array}$ & $\begin{array}{c}6 \pm \\
0.31 \mathrm{a}\end{array}$ & $\begin{array}{c}0.39 \pm \\
0.047 \mathrm{a}\end{array}$ & $\begin{array}{l}2.76 \pm \\
0.33 \mathrm{a}\end{array}$ & $\begin{array}{l}0.90 \pm \\
0.46 \mathrm{a}\end{array}$ & $\begin{array}{l}1.86 \pm \\
0.30 \mathrm{a}\end{array}$ & $\begin{array}{l}0.53 \pm \\
0.75 \mathrm{a}\end{array}$ & $\begin{array}{c}56.90 \pm 4 \\
.7 \mathrm{c}\end{array}$ & $\begin{array}{c}2211.75 \pm 90 \\
.74 \mathrm{a}\end{array}$ \\
\hline & $\begin{array}{c}\text { AT } \\
0.05\end{array}$ & $\begin{array}{l}5.84 \pm \\
0.47 \mathrm{a}\end{array}$ & $\begin{array}{c}0.45 \pm \\
0.057 \mathrm{a}\end{array}$ & $\begin{array}{l}2.41 \pm \\
0.21 \mathrm{a}\end{array}$ & $\begin{array}{l}0.93 \pm \\
0.52 \mathrm{a}\end{array}$ & $\begin{array}{l}1.48 \pm \\
0.22 \mathrm{a}\end{array}$ & $\begin{array}{l}0.67 \pm \\
0.80 \mathrm{a}\end{array}$ & $\begin{array}{c}45.1 \pm \\
3.3 \mathrm{~b}\end{array}$ & $\begin{array}{c}2233.4 \pm \\
97.56 \mathrm{a}\end{array}$ \\
\hline \multirow{3}{*}{$\begin{array}{c}4^{\text {th }} \\
\text { wee } \\
\mathbf{k}\end{array}$} & Cont. & $\begin{array}{l}5.18 \pm \\
0.47 \mathrm{a} \\
\end{array}$ & $\begin{array}{c}0.37 \pm \\
0.019 \mathrm{a}\end{array}$ & $\begin{array}{l}2.42 \pm \\
0.10 \mathrm{a}\end{array}$ & $\begin{array}{l}0.94 \pm \\
0.29 \mathrm{a} \\
\end{array}$ & $\begin{array}{l}1.49 \pm \\
0.11 \mathrm{a}\end{array}$ & $\begin{array}{l}0.65 \pm \\
0.60 \mathrm{a}\end{array}$ & $\begin{array}{c}43.2 \pm \\
1.5 \mathrm{a}\end{array}$ & $\begin{array}{l}1969.7 \pm \\
172.75 \mathrm{a} \\
\end{array}$ \\
\hline & $\begin{array}{c}\text { AT } \\
0.02 \\
\end{array}$ & $\begin{array}{l}5.95 \pm \\
0.41 \mathrm{a} \\
\end{array}$ & $\begin{array}{c}0.38 \pm \\
0.019 \mathrm{a}\end{array}$ & $\begin{array}{l}2.27 \pm \\
0.12 \mathrm{a}\end{array}$ & $\begin{array}{l}0.96 \pm \\
0.89 \mathrm{a} \\
\end{array}$ & $\begin{array}{l}1.31 \pm \\
0.13 \mathrm{a}\end{array}$ & $\begin{array}{l}0.78 \pm \\
0.12 \mathrm{a}\end{array}$ & $\begin{array}{c}44.25 \pm 2 \\
.8 \mathrm{a} \\
\end{array}$ & $\begin{array}{c}2377.71 \pm \\
182.95 \mathrm{a}\end{array}$ \\
\hline & $\begin{array}{c}\text { AT } \\
0.05\end{array}$ & $\begin{array}{c}5.6 \pm 0 . \\
17 \mathrm{a} \\
\end{array}$ & $\begin{array}{c}0.38 \pm \\
0.026 \mathrm{a}\end{array}$ & $\begin{array}{c}2.31 \pm \\
0.7 \mathrm{a} \\
\end{array}$ & $\begin{array}{l}0.91 \pm \\
0.15 \mathrm{a} \\
\end{array}$ & $\begin{array}{l}1.41 \pm \\
0.64 \mathrm{a} \\
\end{array}$ & $\begin{array}{l}0.65 \pm \\
0.28 \mathrm{a}\end{array}$ & $\begin{array}{c}41.99 \pm 1 \\
.9 \mathrm{a} \\
\end{array}$ & $\begin{array}{c}2225.1 \pm \\
35.59 \mathrm{a} \\
\end{array}$ \\
\hline
\end{tabular}

Means in the same column not followed by the same letter differ significantly $(\mathrm{P}<0.05)$. 
Table (4): Serum Lipid Profile parameters (Mean \pm S.E.) in Chickens experimentally treated with atorvastatin.

\begin{tabular}{|c|c|c|c|c|c|c|}
\hline $\begin{array}{c}\text { Time } \\
/ \\
\text { Week }\end{array}$ & Group & $\begin{array}{c}\text { Cholesterol } \\
\mathrm{mg} / \mathrm{dl}\end{array}$ & $\begin{array}{l}\text { Total lipid } \\
\text { mg/dl }\end{array}$ & $\begin{array}{c}\text { TG } \\
\mathrm{mg} / \mathrm{dl}\end{array}$ & $\begin{array}{l}\text { HDL } \\
\mathrm{mg} / \mathrm{dl}\end{array}$ & $\begin{array}{l}\text { LDL } \\
\text { mg/dl }\end{array}$ \\
\hline \multirow{3}{*}{$\begin{array}{c}2^{\text {nd }} \\
\text { week }\end{array}$} & Cont. & $202.2 \pm 1.96 \mathrm{c}$ & $1380.4 \pm 14.1 \mathrm{c}$ & $156 \pm 3.3 c$ & $132.6 \pm 1.3 \mathrm{c}$ & $38.4 \pm 2.6 \mathrm{c}$ \\
\hline & $\begin{array}{l}\text { AT } \\
\mathbf{0 . 0 2}\end{array}$ & $109.2 \pm 1.02 \mathrm{~b}$ & $1114 \pm 16.96 b$ & $93 \pm 2.7 b$ & $105.5 \pm 1.4 \mathrm{~b}$ & $14.9 \pm 0.48 b$ \\
\hline & $\begin{array}{l}\text { AT } \\
0.05\end{array}$ & $104.6 \pm 1.29 \mathrm{a}$ & $981.6 \pm 29.1 \mathrm{a}$ & $62.4 \pm 4.6 \mathrm{a}$ & $100.9 \pm 1.5 \mathrm{a}$ & $8.8 \pm 0.33 \mathrm{a}$ \\
\hline \multirow{3}{*}{$\begin{array}{c}4^{\text {th }} \\
\text { week }\end{array}$} & Cont. & $193 \pm 3.44 b$ & $1381 \pm 20.93 b$ & $179 \pm 3.9 \mathrm{c}$ & $101.3 \pm 1.94 \mathrm{c}$ & $55.9 \pm 2.7 \mathrm{c}$ \\
\hline & $\begin{array}{l}\text { AT } \\
0.02\end{array}$ & $81 \pm 2.19 \mathrm{a}$ & $913 \pm 17.34 \mathrm{a}$ & $100.6 \pm 0.51 b$ & $75.2 \pm 2.13 b$ & $14.3 \pm 0.31 b$ \\
\hline & $\begin{array}{l}\text { AT } \\
0.05\end{array}$ & $87 \pm 1.38 \mathrm{a}$ & $923.4 \pm 28.14 \mathrm{a}$ & $62.2 \pm 3.57 \mathrm{a}$ & $66.2 \pm 1.91 \mathrm{a}$ & $8.36 \pm 0.41 \mathrm{a}$ \\
\hline
\end{tabular}

Means in the same column not followed by the same letter differ significantly $(\mathrm{P}<0.05)$.

Table (5): Some Oxidative Stress parameters (Mean \pm S.E.) in Chickens experimentally treated with atorvastatin.

\begin{tabular}{|c|c|c|c|c|c|}
\hline $\begin{array}{l}\text { Time / } \\
\text { Week }\end{array}$ & Group & $\begin{array}{c}\text { GSH } \\
\text { mg/dl }\end{array}$ & $\begin{array}{c}\text { Catalase } \\
\mathbf{u} / \mathbf{m l}\end{array}$ & $\begin{array}{c}\text { MDA } \\
\text { nmol/ml }\end{array}$ & $\begin{array}{l}\text { SOD } \\
\mathrm{mg} / \mathrm{dl}\end{array}$ \\
\hline \multirow{3}{*}{$\begin{array}{c}2^{\text {nd }} \\
\text { week }\end{array}$} & Cont. & $\begin{array}{l}0.42 \pm \\
0.18 \mathrm{a}\end{array}$ & $\begin{array}{l}1271 \pm \\
9.92 \mathrm{c}\end{array}$ & $\begin{array}{c}14 \pm \\
1.05 \mathrm{~b}\end{array}$ & $\begin{array}{c}209.51 \pm \\
4.8 \mathrm{~b}\end{array}$ \\
\hline & AT 0.02 & $\begin{array}{l}0.35 \pm \\
0.41 \mathrm{a}\end{array}$ & $\begin{array}{l}1148 \pm \\
13.2 b\end{array}$ & $\begin{array}{c}11 \pm \\
0.71 \mathrm{a}\end{array}$ & $\begin{array}{c}173.8 \pm \\
1.1 \mathrm{a}\end{array}$ \\
\hline & AT 0.05 & $\begin{array}{l}0.48 \pm \\
0.61 \mathrm{a}\end{array}$ & $\begin{array}{l}584 \pm \\
15.7 \mathrm{a}\end{array}$ & $\begin{array}{l}10.4 \pm \\
0.23 \mathrm{a}\end{array}$ & $\begin{array}{c}172.35 \pm \\
4.92 \mathrm{a}\end{array}$ \\
\hline \multirow{3}{*}{$\begin{array}{c}4^{\text {th }} \\
\text { week }\end{array}$} & Cont. & $\begin{array}{l}1.12 \pm \\
0.88 \mathrm{~b}\end{array}$ & $\begin{array}{c}1520.4 \pm \\
11.14 \mathrm{c}\end{array}$ & $\begin{array}{l}9.4 \pm \\
0.23 b\end{array}$ & $\begin{array}{c}202.88 \pm \\
2.04 \mathrm{~b}\end{array}$ \\
\hline & AT 0.02 & $\begin{array}{c}0.49 \pm \\
0.55 \mathrm{a}\end{array}$ & $\begin{array}{l}1141 \pm \\
4.29 b\end{array}$ & $\begin{array}{c}6.2 \pm \\
0.37 \mathrm{a}\end{array}$ & $\begin{array}{c}261.94 \pm \\
1.77 \mathrm{a}\end{array}$ \\
\hline & AT 0.05 & $\begin{array}{l}0.38 \pm \\
0.13 \mathrm{a}\end{array}$ & $\begin{array}{c}530 \pm \\
44.47 \mathrm{a}\end{array}$ & $\begin{array}{l}5.6 \pm \\
0.4 \mathrm{a}\end{array}$ & $\begin{array}{c}273.3 \pm \\
1.13 \mathrm{a}\end{array}$ \\
\hline
\end{tabular}

Means in the same column not followed by the same letter differ significantly $(\mathrm{P}<0.05)$. 
Table (6): Some Immune Response parameters (Mean \pm S.E.) in Chickens experimentally treated with atorvastatin.

\begin{tabular}{|c|c|c|c|c|}
\hline Time / Week & Group & TNFa & IL1 $\beta$ & IL6 \\
\hline \multirow{3}{*}{$2^{\text {nd }}$ week } & Cont. & $14.93 \pm 1.63 \mathrm{a}$ & $32.43 \pm 2.66 \mathrm{a}$ & $21.57 \pm 1.44 \mathrm{a}$ \\
\hline & AT 0.02 & $35.57 \pm 5.30 \mathrm{~b}$ & $43.53 \pm 1.43 b$ & $33.7 \pm 1.24 \mathrm{~b}$ \\
\hline & AT 0.05 & $53.07 \pm 4.29 c$ & $45.67 \pm 2.71 b$ & $35.77 \pm 2.43 \mathrm{~b}$ \\
\hline \multirow{3}{*}{$4^{\text {th }}$ week } & Cont. & $14.93 \pm 1.63 \mathrm{a}$ & $32.43 \pm 2.66 \mathrm{a}$ & $21.57 \pm 1.44 \mathrm{a}$ \\
\hline & AT 0.02 & $60.47 \pm 1.85 b$ & $47 \pm 4.88 b$ & $55.10 \pm 5.76 \mathrm{~b}$ \\
\hline & AT 0.05 & $65.17 \pm 1.99 b$ & $46.93 \pm 4.23 b$ & $44.83 \pm 2.83 \mathrm{~b}$ \\
\hline
\end{tabular}

Means in the same column not followed by the same letter differ significantly $(\mathrm{P}<0.05)$.

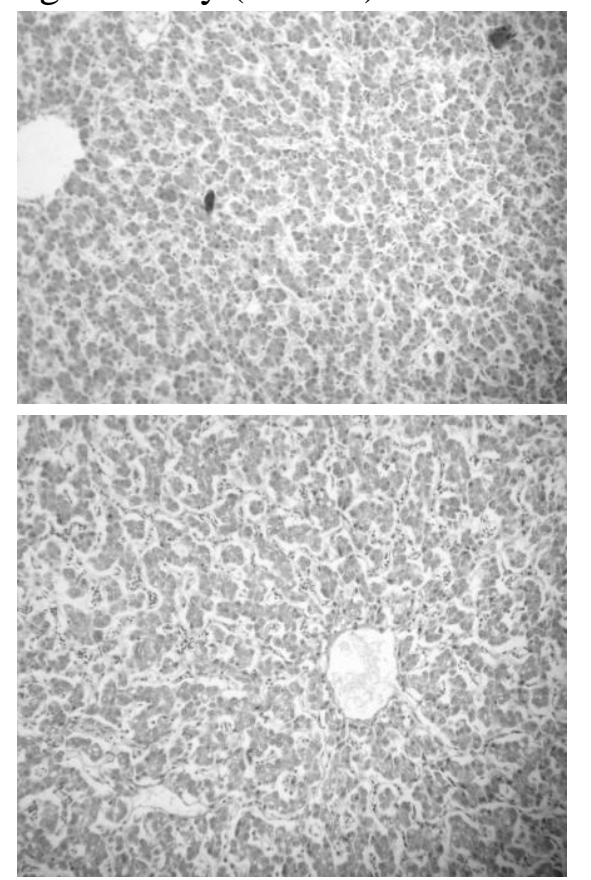

Fig, (1): liver of control groups chickens showing apparently healthy tissue.

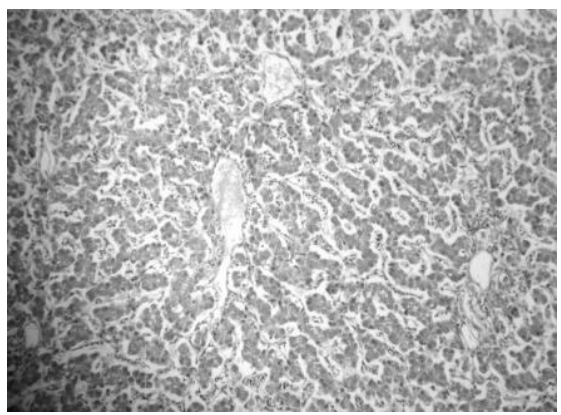

Fig, (3): liver of chickens experimentally treated with atorvastatin $0.05 \%$ showing hepatic degeneration besides some coagulative necrosis of some hepatocytes infiltrated with round cells. 
REFERENCE:

Anderson ME and Meister A (1989): Glutathione monoesters. Anal Biochem; 183:16- 20.

Asaf AQ and David MP (2001): The combined effects of novel tocotrinol and lovastatin on lipid metabolism in chickens. Atherosclerosis; 156:39-47.

Aukrust P, Liabakk NB, MÜller F, Lien E, Espevik T and Froland SS (1994): Serum level of tumor necrosis factor- $\alpha$ and soluble TNF receptors in human immunologic virus type 1 infection correlation to clinical immunologic and virologic parameters .J.Inf.Dis; 169: 420-424. Aydina S, Uzuna H, Sozer $V$ and Altug T (2009): Effects of atorvastatin therapy on protein oxidation and oxidative DNA damage in hypercholesterolemic rabbits. Pharmacological Research; 59:242-247.

Barbara AB (1988): Hematology Principles and Procedures, 5th ed. Lee and Fedbiger, Philadelphia, USA; pp: 81-83.

Bastard J, Jardel C, Delattre J and Hainque B (1999): Evidence for a Link between adipose tissue interleukin-6 content and serum Creactive protein concentrations in obese subjects. Circulation; 99 (16): 2219-2222.

Black DM (2002): A general assessment of the safety of HMG CoA reductase inhibitors (statins). Curr Atheroscler Rep; 4: 34-41.

Brown MS and Goldstein JI (1986): A receptor mediated pathway for cholesterol homeostasis. Science; 232:34-47.

Chan and Perlstein (1987): Immunoassay: A Practical Guide, Academic Press: NewYork.p71.

Clarke AT and Mills PR (2006): Brief clinical observation: atorvastatin associated liver disease.

Dig Liver Dis; 38:772-777.

Coles EH (1986): Veterinary Clinical Pathology. 4th ed, pp (27997). WB Saunders Company, Philadelphia.

Daghir NJ (1995): Poultry Production in Hot Climate. PP 2 $\mathrm{CAB}$ International. Cambridge.

Davidarj C, Jipnomon J, Mohamed M, Gayathri $K$ and Govindha PD (2008): Psychoemotional stress- A cause of coronary artery disease. Acta Scientia Veterinariae; 36(2):133139.

Drabkin JN (1997): Standardization of hemoglobin measurement in" Fish

Medicine"stoskopf K.M, (ed), $1^{\text {st }}$ ed; W.B Saunders co. Philadelphia, pp 114-115.

Edward PA and Davis R (1996): Isoprenoids, sterols and bile acids, Biochemistry of lipids, lipoprotein and membranes. Elsevier, Amsterdam PP; 341-362.

Ebru DS, Eser YS, Deniz N and Taner O (2011): Effect of atorvastatin therapy on oxidantantioxidant status and atherosclerotic plaque formation. Vascular Health and Risk Management; 7:333-343. 
Feldman BF, Zinkl JG and Jain VC (2000): Schalm's Veterinary Hematology 5th ed. Lippincott Williams and Wilkins Canda; pp: 1145-1146.

Gehan HH and Manal IA (2010):

Effect of combined administration of ginger (Zingiber officinale Roscoe) and atorvastatin on the liver of rats.Phytomedicine; 17:1076-1081

Goldstein JL and Brown MS (1990): Regulation of the mevalonate pathway. Nature London; 343:425-35.

Illingrowth DR (1987): Lipid lowering drugs: an overview of inductions and optimum therapeutic use. Drug; 33:259-79.

Isogai $\mathbf{E}$, Isogai $\mathbf{H}$, Kimura $\mathbf{K}$ ,Hayashi S, Kubota T, Fujii $\mathrm{N}$ and Takeshi K(1998): Role of tumor necrosis factor alpha in gnotobiotic mice infected with an Escherichia coli $0157: \mathrm{H} 7$ strain.Infection and Immunity; 66:197-202.

Istvan ES and Deisenhofer $\mathbf{J}$ (2001): Structural mechanism for statin inhibition of HMG-CoA reductase. Science; 292:1160.

Jordan FTW (1990):Poultry Disease .3rd ed. Bailliere Tindall. London.

Joseph, PM, Matt, RS and Claire, MD (2001): Early Response Cytokines and Innate Immunity: Essential Roles for TNF Receptor 1 and Type I IL-1 Receptor during Escherichia coli Pneumonia in Mice. The Journal of Immunology; 166: 4042-4048.
Kaneko JJ, John WH and Micheal LLB (1997): Clinical Biochemistry of domestic animals .5 th ed. Academic Press, New Yourk.

Karatzis E, Lekakis $\mathbf{J}$ and Papamichael C (2005): Rapid effect of pravastatin on endothelial function and lipid peroxidation in unstable angina. Int $\mathbf{J}$ Cardiol; 101:65-70.

Kasim SE, LeBoeuf RC, Khilnani $S$, Tallapaka L, Dayananda $D$ and Jen KL (1992): Mechanisms of triglyceride-lowering effect of HMGCoA reductase inhibitor in a hypertriglyceridemic model, the Zucker obese rat. J Lipid Res; 33:17.

Kim JH, Hong ST, Lee HS and Kim HJ (2004): Oral administration of Pravastatin reduces egg cholesterol but not plasma cholesterol in laying hens. Poultry Science; 83:1539-1543.

Ma PTS, Gil G, Sudhf TC, Bilheimer DW, Goldstein JL and Brown MS (1986):Mevinolin, an inhibitor of cholesterol synthesis, induces mRNA for low density lipoprotein receptor in livers of hamsters and rabbits. Proc Natl Acad Sci USA; 83:8370-8374.

Martha S, Akula A and Yellu NR (2008): Anti-atherosclerotic effect of atorvastatin and clopidogrel alone and in combination in rats. Indian Journal of Experimental Biology vol.46, pp; 698-703.

Meister $A$ and Anderson ME (1983):Glutathione. Ann Rev Biochem; 52:711-60. 
Michele MB, Ester R, Celina MY, Wagner LT, Danielle GS, Vanessa P, Maria SAC and Mauro MT (2005): Antiinflammatory and analgesic effects of atorvastatin in a rat model of adjuvant-induced arthritis. European Journal of Pharmacology; 516: $282-289$.

Nakanishi M, Goldstein JL, and Brown MS (1988): Multivalent control of 3-hydroxy-3methylglutral coenzyme A reductase: mevaonate derived product inhibits translation of mRNA and accelerates degradation of enzyme. J Biol Chem; 263:892937.

Naoumova RP, Marais AD and Mountney J (1996): Plasma mevalonic acid, an index of cholesterol synthesis in vivo, and responsiveness to HMG-CoA reductase inhibitors in familial hypercholesterolemia.

Atherosclerosis; 119:203-213.

Parkre RA, Pearce BC, Clark RW, Gordon DA, and Wright JJK (1993):

Tocotrinol regulate cholesterol production in mammalian cells by post-transcriptional suppression of 3-hydroxy-3-methylglutral coenzyme A reductase .J Biol Chem; 268:11230-8.

Parra, J L, Reddy, and $\mathbf{K} \mathbf{R}$ (2003): Hepatotoxicity of hypolipidemic drugs. Clin Liver Dis; 7:415-433.

Rebecca GBA, James B, Rana F , Therese MHA , David M , James WN and Donald MB (1997): A brief review paper of the efficacy and safety of atorvastatin in early clinical trials. Atherosclerosis; 131:17-23.

Robert GK, Yuan Z, Shawn SD , Elke HO and Wolfgang JS (2006): Effects of atorvastatin on lipid metabolism in normolipidemic and hereditary hyperlipidemic, non laying hens. Comparative Biochemistry and Physiology, part B; 143:319-329.

Saeed N, Mahdi S, Hasan B and Saeedeh S (2009): Influence of road transportation during hot summer conditions on oxidative statue biomarkers in Iranian dromedary camels (camelus dromedarius). African Journal of Biochemistry Research Vol; 3(7):282-287.

Shaw MK, Newton RS, Sliskovic DR, Roth BD, Ferguson $E$ and Krause BR (1990): Hep-G2 cells and primary rat hepatocytes differ in their response to inhibitors of HMG-CoA reductase. Biochem Biophys Res Commun; 170:726734.

Stadtman ER (2004): Role of oxidant species in aging. Curr Med Chem ; 11:1105-12.

Uma S, Sridevi D, Ishwarlal J and David S (2008): Comparison effect of atorvastatin (10 versus $80 \mathrm{mg}$ ) on biomarkers of inflammation and oxidative stress in subjects with metabolic syndrome. Am J Cardiol; 102:321-325.

Veillard, NR and Mach F (2002): Statins: the new aspirin? Cell Mol Life Sci; 59:1771- 1786. 
Waters DD (2005): Safety of highdose atorvastatin therapy.Am.J Card 96, 69F-75F.atherosclerosis .J Am Coll Cardiol; 35: 1-10.

Wainwright CL (2005): Statins: is there no end to their usefulness? Cardiovas Res; 65:296-298.
Yogendrasinh BS and Rajendra VB (2010): Effects of antioxidant vitamins along with atorvastatin and atorvastatin-niacin combination on diet-induced hypercholesterolemia in rats. Int $\mathbf{J}$ Physiol Pathophysiol Pharmacol; 2(1):57-63.

\section{الملخص العربي}

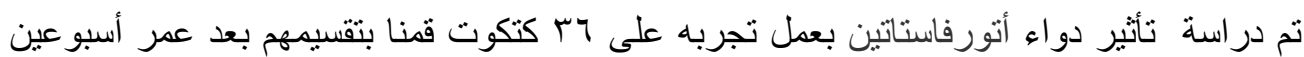

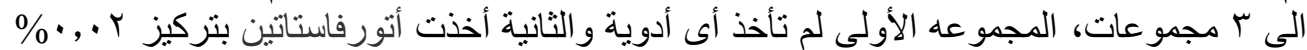

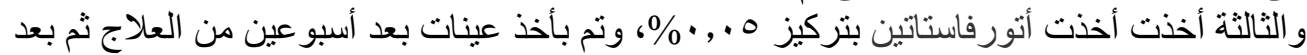

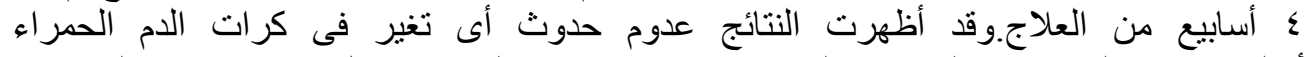

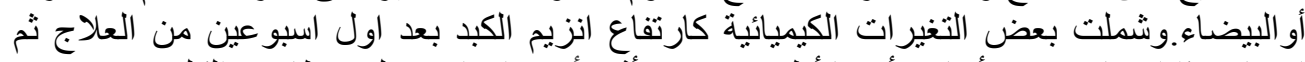

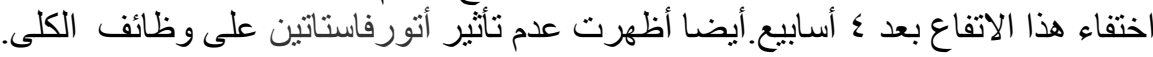

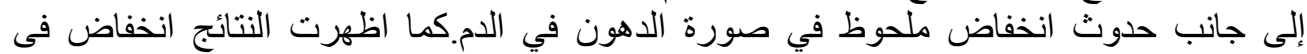
الانزيمات المؤكسدة فى الدم وتحسن المناعة. 